\title{
Metropolis and We
}

\author{
Oleg Koshkin \\ Russian Academy of Arts \\ Moscow, Russia \\ E-mail: obr.rah@rah.ru
}

\begin{abstract}
The present article is concerned with one of the pressing challenges of urban architecture, the preservation of cities' historic architectural heritage in the framework of modern construction and renovation of architectural monuments. The problem is reviewed in historical aspect from ancient times to the present day. Primarily, the author draws attention to the reconstruction of Moscow' historic buildings and the 'new' architecture of the city.
\end{abstract}

Keywords-architectural heritage; architectural monuments; national culture; reconstruction; re-creation of the cathedral of Christ the Saviour; Moscow; architecture; artistic concept of the capital

\section{INTRODUCTION}

Debates over the future of historical heritage of cities and permissible limits of their renovation have intensified lately, the opponents got tough in their dispute over the preservation of every or almost every architectural monument, which is important for the city's appearance, with or without its official status, and its 'reconstruction'. The latter suggests usually either the old buildings' construction new, or their inclusion into modern housing complexes. The problem of preserving the historic appearance of the city is not just the job-related problem of architects. They can suggest ways of implementing the principal decisions adopted by either public officials or the society. Needless to say that this is not about opinion polls or plebiscite. The development of one's attitude to the history of own country and own town cannot be solved in such ways. This needs a much more complex and an obviously long journey towards the development of awareness of the previous generations' heritage and of its role in the national culture. Only then may the ancient capital's artistic appearance be successfully shaped.

\section{HistoricAl HERITAGE OF URBAN ARCHITECTURE}

Only structures and sites (squares, sacred groves, hills, and springs) declared the religious or state relics, or which had been considered worthy to follow, managed to survive throughout the course of history.

A facility' functions coincided quite often - the Attic Parthenon had been both the most revered temple of the goddess Pallas Athena and the gold standard for many generations of ancient architects. The St. Peter's Basilica in Rome commemorated the apostle's grave and at the same time set the pattern for the Renaissance and more recent architects.
In the Soviet times, the historical status of Moscow, in the ideological context, remained unspecified. It hardly fitted the communist bright future, since encapsulated too many memories and symbols of the Tsarist-times history. The practical requirements of the Soviet ideology demanded, nonetheless, clear evidence of the nation's centuries-old fundamental strength, instruments of patriotic education, and, beyond that, the evidence of the high-level culture that would be recognized in the entire world. Moscow's architectural monuments with their outstanding, expressive artistic characters and the association with Russia's landmark events were aligned with such requirements. Most of the Muscovites were taking their town as a place of their habitual, everyday life, causing a sensation of affection and love, rather than as an official and ideologically charged space.

Following the Soviet times, there was a certain vacuum in the vision of the city historical values. The preserved authentic monuments continued to play their historical role without acquiring the role of new symbols of the city and the nation. The Kremlin's status, for instance, has practically not changed in the eyes of public.

\section{ARCHITECTURAl HERITAGE, RECONSTRUCTION AND REVIVAL OF ARCHITECTURAL HERITAGE}

After the fall of the USSR, the destroyed by communists buildings of the past, which had an immense sense-bearing content, became the avant-garde of Moscow's new architectural ideology. Ideological vacuum in the capital city was starting to be filled with a "new" past, an "ultramodern antiquity", namely the modernization of Moscow historical buildings one-to-one.

The process got underway quite unpretentiously from a small church of the Kazan Icon of the Mother of God on Red Square "Fig. 1". Later reconstruction of the adjacent Iversk Gates of Kitay-Gorod (also referred to as the Great Possad) and of the chapel at the Gates - one of the most venerated places in Moscow in the past because of the presence there of the miraculous Iberian icon- made a bigger splash. The project became the place of the 'collision of interests' of ancient and Soviet architectural horizons. The Iversk Gates were obstructing the established passage of vehicles during military parades on Red Square. At first, this caused misunderstanding, but, eventually, everyone agreed that this was advantageously emphasizing the country's peaceful disposition. 


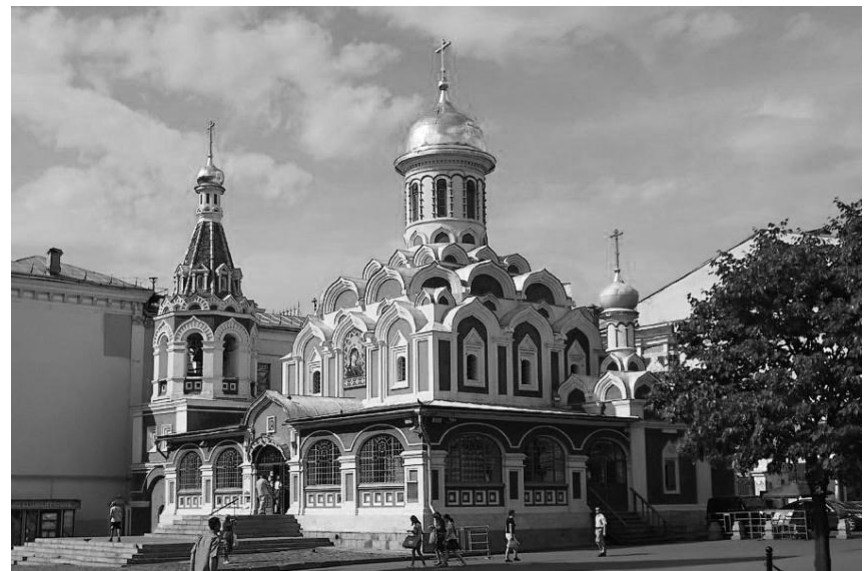

Fig. 1. The Cathedral of the of the Mother of God on Red Square in Moscow.

Reconstruction of the Cathedral of Christ the Saviour became the pinnacle event of new historicism in Moscow's modern transformation. Today, there are still many opponents of such far-reaching redevelopment. Yet, just imaging the construction of some trading centre or apartment homes in place, which would certainly had happened, if the Cathedral had not appeared. Completed to the bimillennium of the Nativity of Christ, to which the Cathedral is dedicated, it became one of the world's outstanding monuments marking the turn of millennia.

No matter how much has been done in all countries worldwide, no one had never created such a magnificent monument of academic tradition in fine art. In fact, this was in the nature of Russia. One can hardly escape from the acknowledgement that these very traditions dominated the artistic culture of Imperial Russia for at least 300 years. The sum of our memories about the latter had been accumulated in the Cathedral of Christ the Saviour.

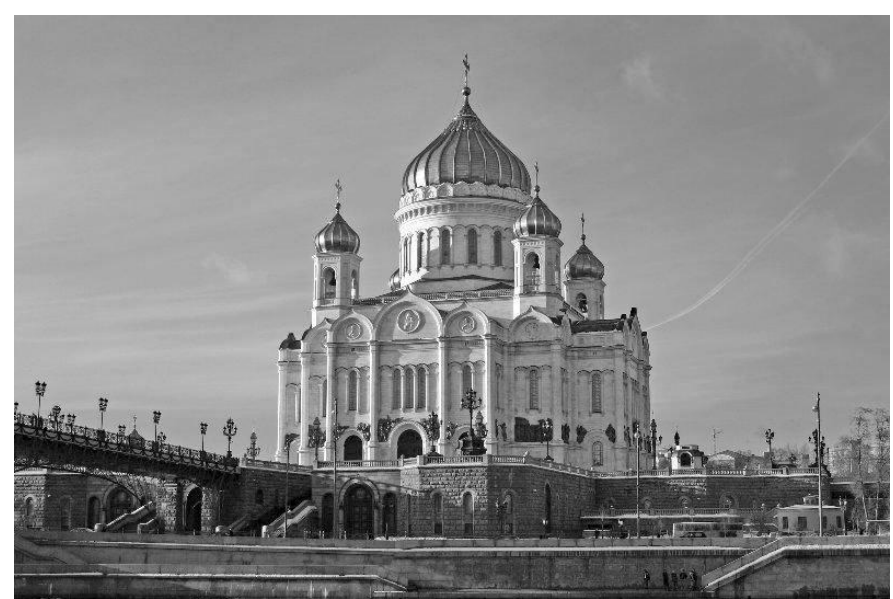

Fig. 2. The Cathedral of Christ the Saviour in Moscow re-created with the participation of the Russian Academy of Arts.

The Cathedral had showed itself from yet another unexpected side. Its grand skyline, the dome towering high managed to mobilize what had remained in the town from the space of the 19th century. Streets, passages and bridges once again had received the landmark to which they were once directed-this restored their import in the urban structure.

Neo-historicism in Moscow had lapsed after the completion of the Cathedral of Christ the Saviour. Perhaps, primarily due to high prices, but not only. Supposing the reconstruction of buildings, which were destroyed in previous times, continued, the city concept would become then emphatically retrospective. This obviously did not reflect the intentions of the state or municipal authorities.

\section{IV. "NEW DESIGN" OF Moscow}

The idea of restoring the lost symbols of the past in the mid-1990s gave way to the new concept of Moscow as a city of European civilization, a modern metropolis, brought into the world by new Russia. Transformation of the urban road network, its modern junctions and the 'third traffic ring' have added to the image of Moscow indispensable attributes of an Occidental urban centre, although there is a lot more to do to decide all transportation problems here.

Finally, almost all European retails have occupied Soviet shopping areas. Among the legion of exclusive fashion boutiques, where you do not often meet a large number of customers, they seem to be symbols rather than real commercial enterprises.

In recent years, the main architectural efforts have focused on the design of elite housing and bank premises. Despite their different functions, stylistically these facilities present almost one international style. Neoclassicism and neomodern, which address to Moscow's architecture of the early 19th century or Soviet Empire style, but hardly ever reach the level of their architectural and artistic appearance, are gaining popularity with residential facilities' design. "Fig. 3" and "Fig. 4"

Flat colonnaded or all-glass facades are concealing similar building technologies with steel skeleton and compound walling.

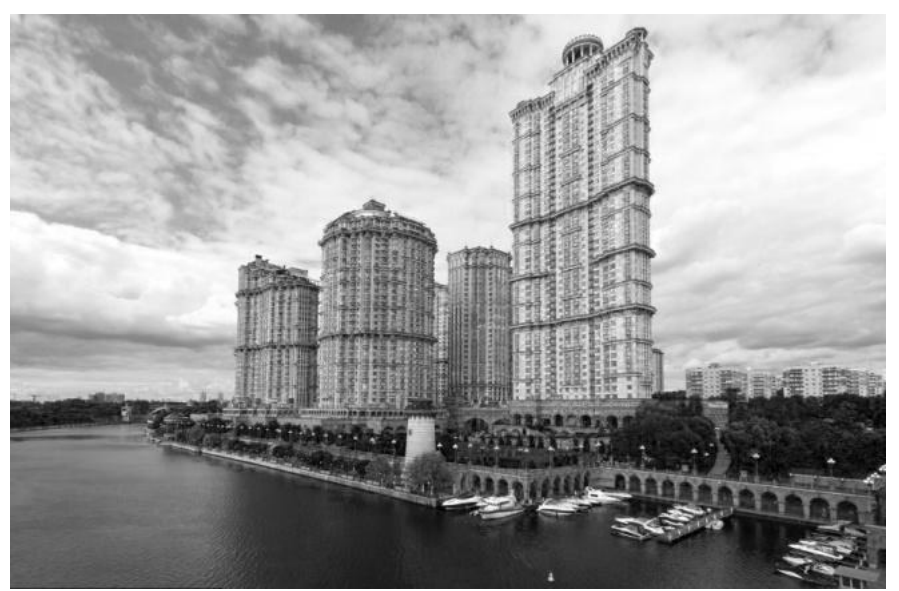

Fig. 3. New luxury housing in Moscow (“Alye Parusa” housing estate and other). 


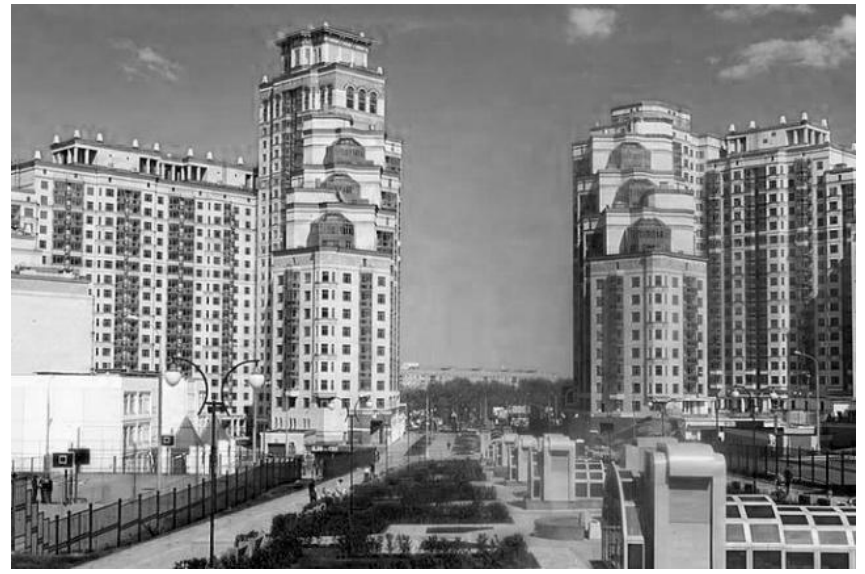

Fig. 4. New luxury housing in Moscow ("Alye Parusa" housing estate and other).

Hardly anybody is surprised at the quality of Moscow's new architecture. It startles by another thing-by its balance with the city's historical heritage. Old humble buildings are disappearing through the capital's historic centre with a dizzying speed.

Outstanding historic antiquities are being regularly restored, and their growing number begins to look 'as neat as a pin'. This, however, can be reconciled since Moscow weather and ecology are likely to return to the buildings the patina of antiquity. Trying to preserve historic architectural heritage of the city, specialists often disregard its setting and ordinary buildings that provide the essential background for the perception of famous buildings. Much was said about the heritage protection areas even in the Soviet times. Thus, the General construction plan of Moscow in the 1970s marked out a number of large city areas starting from the back streets of Arbat, designated as the conservation areas, where the historical fabric of the city was to be preserved completely. These ideas have gone with the wind, at least, in real life.

\section{CONCLUSION}

What can we do? To accept the city we are living in as it is and fairly observe its constant changes or to fight for each manor house and each time suffer defeat? Ideally, we do not need the technical concept of the city meant for particular traffic flows, for housing demand and for the resolution of engineering and other needs to solve municipal engineering and other summless challenges. The city needs an art concept too. Let this be the concept, even if it is a utopian dream, feasible or not - time will show-in which Moscow will contend with what it is - a single-piece monument of architecture and city development.

\section{REFERENCES}

[1] Monuments of the Country, Almanac, No. 37 (1, 1997). Restored holy sits of Moscow, M.: All-Russian Society for the Preservation of Historical and Cultural Monuments, 1997.

[2] The Cathedral of Christ the Savior. Recreated sculptural and art decoration, Album, Russian Academy of Arts, M.: Sculptor Foundation
[3] The Cathedral of Christ the Savior, Album, 2nd enlarged edition / Authors: E.I. Kirichenko, A.M. Denisov; Book acquisitions G.A. Ivanova. - M.: Planeta, 1997.

[4] Dmitry Shvidkovsky, "From megalith to metropolis": essays on the history of architecture and city development, M.: Arkhitektura-S, 2009. 